\title{
Phenoloxidases Produced by Endophytic Fungi Isolated from Baccharis Dracunculifolia D. C. (Asteraceae)
}

\author{
Side ne y Becker Onofre ", Paula Steilmann \\ Institute of Biological and Health Sciences, Department of Biological Sciences, Paranaense University (UNIPAR), Unit of Francisco \\ Beltrão, Francisco Beltrão, Paraná, Brazil
}

\begin{abstract}
Phenolic compounds fall within the waste resulting from the biodegradation of natural and anthropogenic, are found in soil and water, but despite being widely distributed in nature are part of the main pollutants toxic waste discarded by a wide variety of industries such as textiles, petroleum refining, pulp and paper, pharmaceuticals, coating metals, wood preservatives, dyes, plastics and resins, coal conversion, and are components of many biocides. In order to remedy the impacts of these compounds, seven endophytic fungal species isolated from Baccharis dracunculifolia D. C. (Asteraceae) were studied to determine their ability to produce phenoloxidases capable of degrading phenolic compounds. The fungi were inoculated in media containing different concentrations of gallic acid, incubated at $28^{\circ} \mathrm{C}$ and mon itored every $48 \mathrm{~h}$. En zy me production was assessed through the observation of an amber-colored halo, which is characteristic of the Bavendamm's reaction. On ly Fusarium sp. strain D3-FB and Cercospora sp. strain D7-FB showed degradation halos at all concentrations. Although developed in the same media, the other species showed no signs of the Bavendamm's reaction.
\end{abstract}

Keywords Phenoloxidases, Baccharis Dracunculifolia, Phenolic Compounds, Endophytic

\section{Introduction}

Industrial processes are a major cause of environmental problems. However, it is through industrialization that food and other essential items are obtained. As industry is of paramount importance, an alternative to solve and reduce the problems caused to the environment is increasingly sought-after[1].

Large-scale industrialization, increase in production, large population concentration in certain regions and intense agricultural activity contribute to the significant rise in waste discharges into watercourses. The improper release of solid, liquid and gas wastes from different sources changes the characteristics of soil, water and air, and it may cause environmental pollution or contamination. Pollution occurs when these residues alter the aesthetic aspect, the composition or the shape of the physical environment, while the environment is considered contaminated when there is a minimal threat to human, animal and plant health.

Bioremediation is a technology that uses microorganisms to reduce or remove petroleum hydrocarbons pollutants from the environment. This technology can be defined as a reaction biologically catalyzed that transforms chemically complex compounds into simp ler substances.

* Corresponding author:

sideney@unipar.br(Sideney Becker Onofre)

Published online at http//journal.sapub.org/re

Copyright (C) 2012 Scientific \& Academic Publishing. All Rights Reserved
In the case of organic compounds, there may be conversion of the original constituents into inorganic substances, a process called mineralization[2].

A variety of organic substances found in oil refinery and industrial effluents are efficiently degraded by bacteria, yeasts and filamentous fungi, due to their ability to use such substances as a carbon and energy source. Such ability makes these organisms an increasingly useful alternative to conventional methods of treatment in the solution of environmental problems [3].

According to Bentro, Camargo and Okeke[4], there are different bioremediation strategies: natural or intrinsic bioremediation, by using autochthonous microorganisms without any interference of active remediation technologies; biostimulation, by adding stimulating agents, such as nutrients, oxygen and biosurfactants; and bioaugmentation, through the inoculation of enriched microbial consortia. The purpose and advantage of these techniques is the mineralization of the pollutant.

Fungi secrete a large variety of enzymes, which are effective when assisting in their nutrition, thus being responsible for the deterioration of various natural, re fined or processed materials[5]. In recent decades, the use of filamentous fungi and their metabolites in bioremediation processes has been growing, due to the high potential of biosorption (heavy metals and dyes), degradation and efficient mechanis ms of resistance to adverse environmental conditions. Among the important industrial enzymes produced by fungi are cellulases, phenoloxidases and tannases[6]. 
The survey and characterization of new strains with biodegradative ability, adaptability to local environmental conditions and tolerance to toxic ity are important aspects yet to be explored in a program that aims to apply bioremediation processes [7].

Another issue to be considered is the wide variety of pollutants, including phenols, released by industries. Although these compounds are found in nature, they are a major residual toxic pollutant, mainly discarded by the petrochemical and textile industries [8].

Many substances considered harmful, such as phenolic compounds, can have their toxicity reduced or eliminated through the action of adapted microorganisms. Environmental conditions, including temperature, $\mathrm{pH}$, oxygen and salinity, can promote or suppress the degradation of these compounds [6].

Some fungi are able to produce phenoloxidases in media containing phenols, through a process called Bavendamm's reaction. Under the action of fungal phenoloxidases, gallic acid forms quinones, which are identified by the formation of an amber-colored halo around the mycelium[2]. The production of phenoloxidases or polyphenol oxidases is extremely important in biotechnology, as these enzymes are responsible for breaking the phenolic groups present in industrial effluents and petroleum hydrocarbons. Microorganisms that produce these enzymes can be easily used in decontamination of polluted environments [9].

This study sought to evaluate the ability of seven species of endophytic fungi isolated from Baccharis dracunculifolia D.C. (Asteraceace) in producing phenoloxidases and degrading phenolic compounds.

\section{Materials and Methods}

\subsection{Fungi Assessed}

The research was conducted in the years 2008 and 2009 with seven species of endophytic fungi isolated from Baccharis dracunculifolia D.C. (Asteraceae), which were maintained in the mycology collection of the Microbiology Laboratory of the University of Parana (UNIPAR), Francisco Beltrão Campus, PR, Brazil. The species used are: Aspergillus sp. strain D2-NC, Fusarium sp. strain D3-FB, Colletotrichum sp. strain D4-FB, Acremonium sp. strain D5-FB, Cercospora sp. strain D7-FB, Cylindrocladium sp. strain D8-FB and Phomopsis sp. strain D10-NC.

\subsection{Culture Medium}

The species were evaluated on a minimal medium (MM), containing $\mathrm{NaNO}_{3} \quad(0.38 \mathrm{~g} / \mathrm{L}), \quad \mathrm{KH}_{2} \mathrm{PO}_{4} \quad(1.19 \mathrm{~g} / \mathrm{L})$, $\mathrm{MgSO}_{4} 7 \mathrm{H}_{2} \mathrm{O}(0.50 \mathrm{~g} / \mathrm{L}), \mathrm{KCl}(0.50 \mathrm{~g} / \mathrm{L}), \mathrm{FeSO}_{4} 7 \mathrm{H}_{2} \mathrm{O}(0.01$ $\mathrm{g} / \mathrm{L})$, agar $(20 \mathrm{~g} / \mathrm{L})$, supplemented with different concentrations of gallic acid $(0.80,1.0,1.20,1.40,1.60$ and $1.80 \mathrm{~g} / \mathrm{L})$.

\subsection{Degradability}

Inoculation was performed on each plate from a sample kept on a PDA culture medium, then incubated at $28^{\circ} \mathrm{C}$ and monitored every $48 \mathrm{~h}$ for a period of $240 \mathrm{~h}$, when the amber-colored halo characteristic of the Bavendamm's reaction occurred. Under the action of fungal phenoloxidases, gallic acid forms quinones, which are identified through the halo formed around the mycelium[2]. Evaluations were conducted every $48 \mathrm{~h}$ and each colony was measured with a millimeter ruler in two diametrically opposite directions to obtain the growth mean in the period.

\section{Results and Discussion}

The ability to produce phenoloxidases and degrade phenolic compounds of the studied species are shown in Table 1.

According to data shown in Table 1, Fusarium sp. strain D3-FB had the best behavior in the degradation of phenolic compounds (represented in this study by gallic acid), followed by Cercospora sp. strain D7-FB. The other five species studied grew on a minimal medium, but the formation of degradation halos of gallic acid by the action of phenoloxidases was not observed (Figure 1). This behavior is shown in Table 1, through positive BR or negative BR.

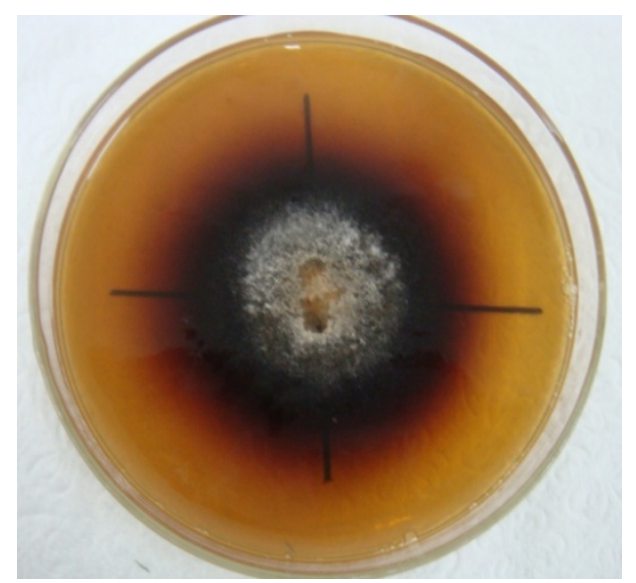

Figure 1. Characteristics of the Bavendamm's reaction caused by the oxidation of gallic acid and the formation of quinones on a Fusarium sp. strain D3-FB culture

The behavior of the five species grown on the minimal medium, with negative results for the BR, may be justified by considering that these are wild strains. Fungi species that are considered wild have the ability to grow on a medium containing salts and using the agar as a substrate[9, 10].

Two tested species, Phomopsis sp. strain D10-NC and Acremonium sp. strain D5-FB, had their growth inhibited from concentrations of $1.0 \mathrm{~g} / \mathrm{L}$ and $1.20 \mathrm{~g} / \mathrm{L}$, respectively. The data obtained in this study match those found by Conceição et al.[6] who evaluated 12 fungi species isolated from mangroves, including Aspergillus sp., Fusarium sp., Colletotrichum sp. and Phomopsis sp. They concluded that all 12 species studied developed in media containing gallic acid. 
Table 1. Halos of degradation of phenolic compounds with mean values, followed by standard deviat ion, obtained through the Bavendamm's reaction after $240 \mathrm{~h}$ of growth

\begin{tabular}{cccccccc}
\hline Fungus \# & $0.80 \mathrm{~g} / \mathrm{L}$ & $1.0 \mathrm{~g} / \mathrm{L}$ & $1.20 \mathrm{~g} / \mathrm{L}$ & $1.40 \mathrm{~g} / \mathrm{L}$ & $1.60 \mathrm{~g} / \mathrm{L}$ & $1.80 \mathrm{~g} / \mathrm{L}$ & $\mathrm{BR}$ \\
\hline 2 & $1.92 \pm 0.51 \mathrm{c}$ & $6.65 \pm 1.14 \mathrm{a}$ & $5.08 \pm 1.98 \mathrm{a}$ & $5.28 \pm 1.92 \mathrm{a}$ & $5.68 \pm 1.12 \mathrm{a}$ & $5.99 \pm 1.82 \mathrm{a}$ & $\mathrm{N}$ \\
3 & $8.11 \pm 1.92 \mathrm{a}$ & $4.98 \pm 1.78 \mathrm{~b}$ & $3.29 \pm 1.15 \mathrm{~b}$ & $4.98 \pm 1.72 \mathrm{a}$ & $4.59 \pm 1.44 \mathrm{a}$ & $498 \pm 1.21 \mathrm{a}$ & $\mathrm{P}$ \\
4 & $7.83 \pm 2.65 \mathrm{a}$ & $1.59 \pm 0.45 \mathrm{c}$ & $1.38 \pm 0.23 \mathrm{c}$ & $1.56 \pm 0.40 \mathrm{c}$ & $1.38 \pm 0.15 \mathrm{~b}$ & $1.97 \pm 0.50 \mathrm{~b}$ & $\mathrm{~N}$ \\
5 & $3.54 \pm 1.92 \mathrm{~b}$ & $0.38 \pm 0.28 \mathrm{c}$ & $\mathrm{NG}$ & $\mathrm{NG}$ & $\mathrm{NG}$ & $\mathrm{NG}$ & $\mathrm{N}$ \\
7 & $3.03 \pm 1.87 \mathrm{~b}$ & $0.98 \pm 0.32 \mathrm{c}$ & $0.58 \pm 0.22 \mathrm{~d}$ & $0.48 \pm 0.21 \mathrm{~d}$ & $0.58 \pm 0.24 \mathrm{c}$ & $0.58 \pm 0.32 \mathrm{c}$ & $\mathrm{P}$ \\
8 & $2.06 \pm 1.71 \mathrm{c}$ & $4.97 \pm 1.74 \mathrm{~b}$ & $3.58 \pm 1.35 \mathrm{~b}$ & $3.99 \pm 1.66 \mathrm{~b}$ & $4.59 \pm 1.27^{\mathrm{a}}$ & $4.96 \pm 1.65 \mathrm{a}$ & $\mathrm{N}$ \\
10 & $3.67 \pm 3.30 \mathrm{~b}$ & $\mathrm{NG}$ & $\mathrm{NG}$ & $\mathrm{NG}$ & $\mathrm{NG}$ & $\mathrm{NG}$ & $\mathrm{N}$ \\
\hline
\end{tabular}

* Means followed by a lower case letter do not differ (between them) at a 5\% level by the Tukey test; BR: Bavendamm's reaction (P-Positive, N-Negative); NG: growth did not happen.

Fungus \#. 2) Aspergillus sp. strain D2-NC; 3) Fusarium sp. strain D3-FB; 4) Colletotrichum sp. strain D4-FB; 5) Acremonium sp. strain D5-FB; 7) Cercospora sp. strain D7-FB; 8) Cylindrocladium sp. strain D8-FB; and 10) Phomopsis sp. strain D10-NC.

Santos and Linardi[11] found similar results when investigating the isolation, identification and selection of microorganis ms obtained from the steel industry effluents containing phenol in concentrations of 0.5 to $0.36 \mathrm{~g} / \mathrm{L}$. The authors isolated 97 fungal cultures able to grow in a Sabouraud's medium supplemented with $0.19 \mathrm{~g}$ phenol per liter. Of these cultures, 15 were selected because they can tolerate a concentration of phenol higher than $0.98 \mathrm{~g} / \mathrm{L}$. Three of these cultures were identified as belonging to the genus Aspergillus and two to the genus Fusarium, again coinciding with the results found here. In this study, six species grew in concentrations equal or greater than $1.0 \mathrm{~g} / \mathrm{L}$. The fungi Fusarium sp. and Cercospora sp. are potentially applicable in industrial processes, but it is necessary to optimize the production of phenoloxidases to improve the process.

\section{Conclusions}

Fusarium sp. and Cercospora sp. can be used as polyphenoloxidase producers, because the Banvedamm's reaction could be observed during this study. All studied species developed on a minimal medium containing gallic acid, but the fungus Phomopsis sp. can only be placed in environments with concentrations equal to or lower than $0.80 \mathrm{~g} / \mathrm{L}$. However, Acremonium sp. may be introduced in environments with concentrations equal to or lower than 1.0 g/L. Fusarium sp. strain D3-FB showed the highest production rates of polyphenol oxidase observed through the Bavendamm's reaction, because it grew on all concentrations of phenol tested.

\section{ACKNOWLEDGEMENTS}

The authors thank the Paranaense University (UNIPAR) for the financial support, through the Program of Research Funding, proclamation 2011, and the Brazilian National Council for Scientific and Technological Development (CNPq) through the Program for Scientific Initiation Scholarships - PIBIC.

\section{REFERENCES}

[1] P.A. Zagatto, and E. Bertoletti, Ecotoxicologia aquática princípios e ap licaçõ es. São Carlos, São Pau lo - Rima Editora, 2006, 478p.

[2] S. P. Samantha, Biodegradabilidade de n-Hexadecano por bactérias livres e imobilizadas em Quitosana. 2006, 123f. Dissertação (Mestrado em Biotecnologia de Produtos Bioativos), Universidade Federal de Pernambuco, Recife, Pernambuco - Brasil.

[3] A. F. P. Ururahy, J. R. N. Pereira and M. D. M. Marins, Desempenho de um biorreator do tipo CSTR no processo de degradação de borra oleosa. Boletim Técnico Petrobrás, vol. 41, no. 3, pp. 125-132, 1998.

[4] F. M. Bentro, F. A.O Camargo and B. Okeke, Bioremediation of soil contaminated by diesel oil. Brazilian Journal of Microbiology, vol. 34, pp. 65-68, 2003.

[5] P.H Raven, R.F Evert and S. E. Eichhorn, Biologia Vegetal. 7 ed. Rio de Janeiro: Guanabara Koogan, 2007. 830 pp.

[6] D. M. Conceição, D. Attili-Angelis, E. D. Bidóia, D.F. Angelis, Fungos filamentosos isolados do Rio Itibaia, São Paulo e Refinaria de Petróleo, biodegradadores de compostos fenólicos. Arq. Inst. Biol, vol. 72, no.1, pp. 99-106, 2004.

[7] C. T. Passos, J. F. M. Burkert, S. J. Kalil and C. A. V. Burkert, Biodegradação de fenol por uma nova linhagem de Aspergillus sp. isolada de um solo contaminado do sul do Brasil. Química Nova, vol. 32, no. 4, pp. 950-954, 2009.

[8] L. S. Sisinno, A. D. Pereira Netto, E. C. P. Rego, G. S. V. Lima, Hidrocarbonetos policíclicos aromáticos em resíduos sólidos industriais: uma avaliação preliminar do risco potencial de contaminação ambiental e humana em áreas de disposição de resíduos. Cadernos de Saúde Pública, vol. 19, no. 2, pp. 671-676, 2003.

[9] E. Espósito and J. L. Azevedo, Fungos: uma introdução à biologia, bioquímica e biotecnologia. Caxias do Sul: Educs. 2002, pp. 510.

[10] A. D. P Netto, J. C. M Dias, G. Arbilla, L. F. Oliveira, P. N. G. Kramers, C. A. Van Der Heliden and J. Barek, Avaliação da 
contaminação humana por hidrocarbonetos policíclicos aromáticos (HAPs) e seus derivados nitrados (NHAPs): uma revisão metodológica. Química Nova, vol. 23, no. 2, pp. 765-773, 2000.
[11] V. L. Santos and V. R. Linardi, Biodegrad ation of phenol by a filamentous fungi isolated from industrial effluents identification and degradation potential. Process Biochemistry, vol. 23, no. 2, pp. 1-7, 2003. 